\title{
Trends in climatic variables and future reference evapotranspiration in Duero Valley (Spain)
}

\author{
R. Moratiel ${ }^{1,2}$, R. L. Snyder ${ }^{3}$, J. M. Durán ${ }^{1,2}$, and A. M. Tarquis ${ }^{2}$ \\ ${ }^{1}$ Universidad Politécnica de Madrid, Departamento de Producción Vegetal, Fitotecnia, 28040 Madrid, Spain \\ ${ }^{2}$ CEIGRAM, Research Centre for the Management of Agricultural and Environmental Risks, 28040 Madrid, Spain \\ ${ }^{3}$ University of California, Dept. of Land, Air and Water Res., Davis, CA 95616, USA
}

Received: 27 January 2011 - Revised: 18 April 2011 - Accepted: 25 May 2011 - Published: 27 June 2011

\begin{abstract}
The impact of climate change and its relation with evapotranspiration was evaluated in the Duero River Basin (Spain). The study shows possible future situations $50 \mathrm{yr}$ from now from the reference evapotranspiration $\left(\mathrm{ET}_{\mathrm{o}}\right)$. The maximum temperature $\left(T_{\max }\right)$, minimum temperature $\left(T_{\min }\right)$, dew point $\left(T_{\mathrm{d}}\right)$, wind speed $(U)$ and net radiation $\left(R_{\mathrm{n}}\right)$ trends during the 1980-2009 period were obtained and extrapolated with the FAO-56 Penman-Montheith equation to estimate $\mathrm{ET}_{\mathrm{o}}$. Changes in stomatal resistance in response to increases in $\mathrm{CO}_{2}$ were also considered. Four scenarios were done, taking the concentration of $\mathrm{CO}_{2}$ and the period analyzed (annual or monthly) into consideration. The scenarios studied showed the changes in $\mathrm{ET}_{\mathrm{o}}$ as a consequence of the annual and monthly trends in the variables $T_{\max }, T_{\min }$, $T_{\mathrm{d}}, U$ and $R_{\mathrm{n}}$ with current and future $\mathrm{CO}_{2}$ concentrations (372 ppm and $550 \mathrm{ppm})$. The future $\mathrm{ET}_{\mathrm{o}}$ showed increases between $118 \mathrm{~mm}(11 \%)$ and $55 \mathrm{~mm}(5 \%)$ with respect to the current situation of the river basin at $1042 \mathrm{~mm}$. The months most affected by climate change are May, June, July, August and September, which also coincide with the maximum water needs of the basin's crops.
\end{abstract}

\section{Introduction}

The combination of two separate processes, where water is lost from the soil surface and from surface leaves by evaporation and from crops by transpiration, is referred to as evapotranspiration (ET). Climatic parameters such as rainfall, wind

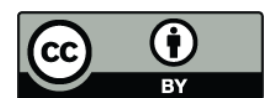

Correspondence to: R. Moratiel (ruben.moratiel@upm.es) speed, radiation, air temperature and air humidity affect the crop water requirements. Global warming, due to the enhanced greenhouse effect, is generating changes in climatic variables such as temperature, absolute humidity, solar radiation and precipitation (IPCC, 2007).

Under the A1B scenario, the annual mean warming from $1980-1999$ to $2080-2099$ varies from $2.2^{\circ} \mathrm{C}$ to $5.1^{\circ} \mathrm{C}$ in Southern Europe and the Mediterranean region (Christensen et al., 2007). According to Räisänen et al. (2004), future warming will be greatest during northern Europe's winters and southern Europe's summers. In the Northern Hemisphere, the air temperature will increase by $0.3^{\circ} \mathrm{C}$ per decade from 1979 through 2005 (Hansen et al., 2001; Smith and Reynolds, 2005; Brohan et al., 2006; Lugina et al., 2007). In Spain the annual daily means temperatures have increased by $0.48^{\circ} \mathrm{C}$ per decade from 1973 through 2005 (Brunet et al., 2007). According to Ceballos-Barbancho et al. (2008), the Duero river basin has a clear trend towards higher temperatures with a mean increase of $0.58^{\circ} \mathrm{C} \mathrm{decade}^{-1}$ between 1973 and 2005.

During the period 1961-1990, the solar radiation trend decreased $1.3 \%$ per decade with observations at land stations around the world (Liepert, 2002). Other authors showed the same trend in China (Ren et al., 2005) and the Mediterranean area (Omran, 2000). Alpert et al. (2005) reported that these reductions can be related to increased urbanisation, anthropogenic aerosol concentration and cloud change (Liepert, 2002). Other authors reported positive global trends in recent studies. Wild et al. (2005) showed that from 1990 onwards, the dimming did not persist, primarily from the Northern Hemisphere. Solar radiation data at Earth's surface, from 1983 to 2001 increased at a rate of 0.16 watts per square meter $(0.10 \%)$ per year (Pinker et al., 2005). 
The global trends of near-surface relative humidity are very small (Trenberth, 2007). The trend in specific humidity between 1976 and 2004 tended to follow surface temperature trends with a global average increase of $0.06 \mathrm{~g} \mathrm{~kg}^{-1}$ per decade (Trenberth, 2007). Moratiel et al. (2010) observed negative trends in relative humidity for Spain with a decrease of $1.1 \%$ per decade of maximum relative humidity and $1.2 \%$ per decade for minimum relative humidity.

There is scarce literature about changes in wind speed in present and future in Europe with low agreement in the conclusions. According to Christensen et al. (2007), changes in wind speed in Spain will remain close to zero, with negative values in the Northeast (decrements of $5 \%$ ), and positive values in the Northwest and South (increments of $5 \%$ ).

Climate Change could potentially affect ET due to changes in air temperature, humidity, wind speed, and effects on cloudiness and atmospheric turbidity which affect net radiation. The increases in the concentration of $\mathrm{CO}_{2}$ also cause reductions in ET rates, due to the stomata closure which cause increases in canopy resistance (Long et al., 2004).

One common feature of regional climate change scenarios is their anticipation of drier summers over continental Europe (Giorgi et al., 2001; Rowell and Jones, 2006). Along with the resulting higher surface heating, drier weather could lead to more water stress and higher demand for water resources (Fink et al., 2004). According to Supit et al. (2010), in various European regions the decreasing water requirement of the annual crops can be attributed to a shorter growing season as a result of increasing temperatures in spring. In same areas of Europe (France and Spain) a reduction of the evaporative demand as a result of the diminishing global radiation has been observed, mainly during summer and autumn for the 1976-2005 period. This can explain the decreasing water requirement for some annual crop such as sugar beets (Supit et al., 2010).

The aim of this study was to estimate the change in reference evapotranspiration $\left(\mathrm{ET}_{\mathrm{o}}\right)$ at the Duero river basin (Spain) $50 \mathrm{yr}$ from now using a standardized PenmanMonteith $\mathrm{ET}_{\mathrm{o}}$ equation. The changes in temperature, dew point, radiation, wind speed and change in canopy resistance were evaluated.

\section{Materials and method}

\subsection{Study area: Duero river basin}

The hydrographic Duero basin is bi-national, and of its $97713 \mathrm{~km}^{2}$ surface area, $81 \%\left(79147 \mathrm{~km}^{2}\right)$ is Spanish territory, and the remaining $19 \%\left(18565 \mathrm{~km}^{2}\right)$ is Portuguese territory (Confederación Hidrográfica del Duero, 2008). The Duero river basin is located in Spain between the meridians $7^{\circ} 4^{\prime} \mathrm{W}$ and $1^{\circ} 50^{\prime} \mathrm{W}$ and the parallels $43^{\circ} 5^{\prime} \mathrm{N}$ and $40^{\circ} 10^{\prime} \mathrm{N}$ (Fig. 1). The Duero basin coincides almost exactly with what is called the Submeseta Norte, a territory of elevated average

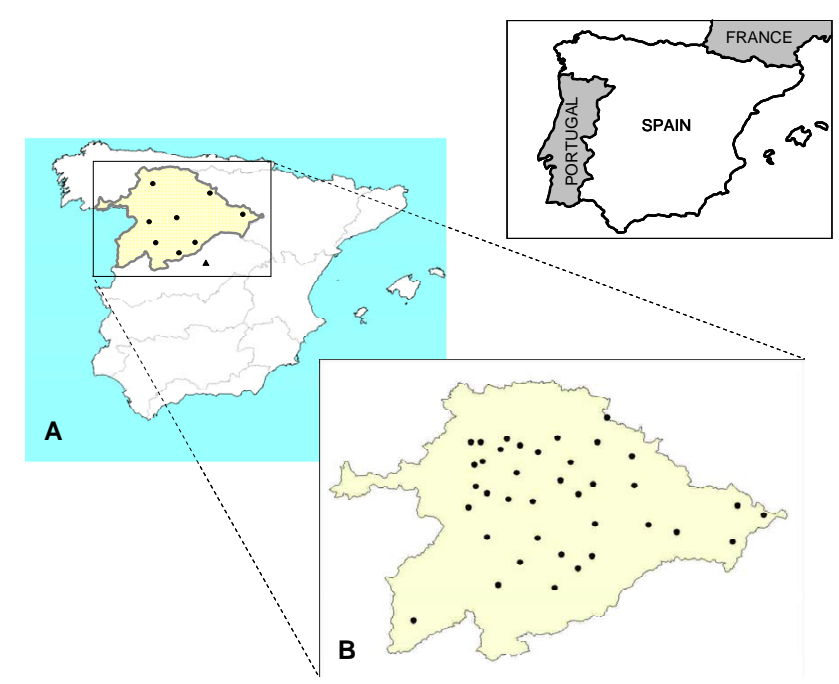

Fig. 1. Location of study area. (A) locations of meteorological stations used to calculate scenarios, points: stations with data for Maximum Temperature $\left(T_{\max }\right)$, Minimum temperature $\left(T_{\min }\right)$ Maximum Relative Humidity $\left(\mathrm{RH}_{\max }\right)$, Minimum Relative Humidity $\left(\mathrm{RH}_{\min }\right)$, Wind Speed $(U)$. Triangle: station with Global Radiation data. (B) locations of agrometeorological stations used to simulate scenarios.

altitude (700 $\mathrm{m}$ a.s.1.), with two distinct parts: one mountainous and the other a prairie region in its central zone. The ring of mountains that surrounds the basin has the greatest rain intensity. The central zone is much drier, but contains the greatest aquifer formations, and this is the most important area of agricultural production. The volume of average annual precipitation in all the Duero basin is around $50000 \mathrm{hm}^{3}$, of which the majority $\left(35000 \mathrm{hm}^{3}\right)$ evaporates or is used directly by the vegetation. The remaining $5000 \mathrm{hm}^{3}$ constitutes the total natural runoff, which flows through surface channels or into the groundwater network though the aquifers. The predominant climate is Mediterranean with summer drought conditions which affect $90 \%$ of the surface of the basin. The average annual temperature is $12^{\circ} \mathrm{C}$ and the average annual precipitation is $618 \mathrm{~mm}$ (Confederación Hidrográfica del Duero, 2008). Considering the threshold of $30 \mathrm{~mm}$ in the definition of the dry month (Lautensach, 1967), the dry periods inside the basin fluctuate between 2 and 5 months (Ceballos et al., 2004).

Barley (Hordeum vulgare L.) is the most important crop in the River Basin with an extension 1300000 ha followed by wheat (Triticum eaestivum L.) with a 700000 ha. Both crops represent $38 \%$ and $34 \%$, respectively, of the National crop surface (MARM, 2010), being considered unirrigated crops, even $10 \%$ of the area is irrigated. Of grain legume crops, the most important are pea (Pisum sativum L.) and vetch (Vicia sativa L.) with $10 \%$ irrigated area and with $55 \%$ of the National crop surface. Sunflower (Helianthus annuиs L.) occupies 200000 ha in the river basin, mainly 
unrrigated and representing $30 \%$ of the National sunflower crop area. Among irrigated crops are maize (Zea mays L.), alfalfa (Medicago sativa L.) and sugar beet (Beta vulgaris L. var. sacharifera) occupy 100000, 64000 and 35000 ha , respectively, representing $30 \%, 30 \%$ and $67 \%$ of each $\mathrm{Na}-$ tional crop area. Vine (Vitis vinifera L.) shows 72000 ha and unirrigated, more than $90 \%$.

\subsection{Climate data}

The climatological data were divided in two groups: those used to identify trends and to make the scenarios, and those in which the obtained scenarios were simulated. For the former, 8 complete stations of meteorological networks (AEMET, 2010) were utilized during the period 1980-2009. In these stations, the variables observed were maximum and minimum temperature, maximum and minimum humidities, wind speed and solar global radiation (Fig. 1a). For the case of solar radiation, as there was no station with this series of data, we used a station outside of the Duero River Basin less than $70 \mathrm{~km}$ away. Net radiation was obtained by means of solar radiation according to the expressions used by Allen et al. (1998). The simulations were not done for the same stations where the scenarios were obtained because for the majority of stations, the necessary sensors for the calculations of daily $\mathrm{ET}_{\mathrm{o}}$ were not available. Moreover, the number of these is very small for the entire Basin. Simulations were applied to daily data from 38 stations (Fig. 1b) of agro-meteorological networks (SIAR, Sistema de información para el Regadío). Each station included the measurements of: solar global radiation (pyranometer SKYE SP1110), air temperature $\left(T_{\mathrm{a}}\right)$ and relative humidity $(\mathrm{RH}$; Vaisala HMP45C), wind speed $(U)$ and wind direction (RM YOUNG 05103 anemometer and wind vane) and precipitation (ARG100 rain gauge). The sensors were periodically maintained and calibrated, and all data were recorded and averaged hourly on a data logger (Campbell CR10X). The agrometeorological network SIAR was created in 1998 and has been widened in subsequent years, becoming completely established in 2001 (MARM, 2010). 2007 was used as a base year to run the simulations, as in this year there was the least fluctuation with respect to the reference period of 1971-2000, as well as smaller deviations from the average temperature of the years from 2001 to 2008. The mean temperature for 2007 was $15^{\circ} \mathrm{C}$, four tenths of a degree higher than for the reference period. These deviations in winter and spring were positive, while in summer and autumn they were insignificant (AEMET, 2010). The daily data for 2007 were downloaded from networks for calculating $\mathrm{ET}_{\mathrm{o}}$.

\subsection{Calculations}

We calculated the annual linear trends of the variables of maximum temperature $\left(T_{\max }\right)$, minimum temperature $\left(T_{\min }\right)$, dew point $\left(T_{\mathrm{d}}\right)$, wind speed $(U)$ and net radiation $\left(R_{\mathrm{n}}\right)$ during the period between 1980-2009. These trends were calculated on a yearly and monthly basis. Subsequently, the MannKendall test was used for this study to determine whether there was a statistically significant trend. The daily data for 2007 were used to calculate reference evapotranspiration $\left(\mathrm{ET}_{\mathrm{o}}\right)$, estimated using the Penman-Monteith equation (Allen et al., 1998, 2006):

$E T_{\mathrm{o}}=\frac{0.408 \Delta\left(R_{\mathrm{n}}-G\right)+\gamma \frac{900}{T+273} u_{2}\left(e_{\mathrm{s}}-e_{\mathrm{a}}\right)}{\Delta+\gamma\left(1+0.34 u_{2}\right)}$

where $\mathrm{ET}_{\mathrm{o}}$ is reference evapotranspiration $\left(\mathrm{mm} \mathrm{day}^{-1}\right), R_{\mathrm{n}}$ is net radiation at the surface $\left(\mathrm{MJ} \mathrm{m}^{-2}\right.$ day $\left.^{-1}\right), G$ is ground heat flux density $\left(\mathrm{MJ} \mathrm{m}^{-2}\right.$ day $\left.^{-1}\right), T$ is mean daily air temperature at $2 \mathrm{~m}$ height $\left({ }^{\circ} \mathrm{C}\right), u_{2}$ is wind speed at $2 \mathrm{~m}$ height $\left(\mathrm{m} \mathrm{s}^{-1}\right), e_{\mathrm{s}}$ is the saturation vapour pressure $(\mathrm{kPa}), e_{\mathrm{a}}$ is the actual vapour pressure $(\mathrm{kPa}), \Delta$ is the slope of the saturation vapour pressure curve $\left(\mathrm{kPa}^{\circ} \mathrm{C}^{-1}\right)$ and $\gamma$ is psychrometric constant $\left(\mathrm{kPa}^{\circ} \mathrm{C}^{-1}\right)$. Equation (1) applies specifically to a hypothetical crop with an assumed height of $0.12 \mathrm{~m}$ having a surface resistance of $70 \mathrm{~s} \mathrm{~m}^{-1}$ and an albedo of 0.23 .

The increase of $\mathrm{CO}_{2}$ provokes the stomata closure and diminishes the ET rates (Long et al., 2004). This increment affects the $\mathrm{ET}_{\mathrm{o}}$ in the term of 0.34 , denominator of the Eq. (1). The 0.34 comes from the following:

$\frac{r_{\mathrm{c}}}{r_{\mathrm{a}}}=\frac{70}{208 / u_{2}} \approx 0.34 u_{2}$

where $r_{\mathrm{c}}$ is a surface resistance $\left(\mathrm{s} \mathrm{m}^{-1}\right)$ and $r_{\mathrm{a}}$ is a aerodynamic resistance $\left(\mathrm{s} \mathrm{m}^{-1} / u_{2}\right)$.

The $r_{\mathrm{c}}=70 \mathrm{~s} \mathrm{~m}^{-1}$ was derived by estimating the typical stomatal resistance $r_{\mathrm{s}}=100 \mathrm{~s} \mathrm{~m}^{-1}$ for the actively transpiring $\mathrm{C}_{3}$ grass leaf surface, which was estimated as half of the $\mathrm{LAI}=2.88$. Therefore, the $0.12 \mathrm{~m}$ tall grass $r_{\mathrm{c}}$ was calculated as (Allen et al., 1998):

$r_{\mathrm{c}}=\frac{r_{\mathrm{s}}}{0.5 \times \mathrm{LAI}}=\frac{100 \mathrm{~s} \mathrm{~m}^{-1}}{0.5 \times 2.88}=69 \approx 70 \mathrm{~s} \mathrm{~m}^{-1}$

Assuming that the $r_{\mathrm{c}}=69 \approx 70 \mathrm{~s} \mathrm{~m}^{-1}$ applies under the current $372 \mathrm{ppm}$ atmospheric $\mathrm{CO}_{2}$ concentration, estimating a new $r_{\mathrm{c}}$ value for higher $\mathrm{CO}_{2}$ provides a method to estimate possible impacts of higher $\mathrm{CO}_{2}$ on $\mathrm{ET}_{\mathrm{o}}$. Note that the canopy conductance corresponding to $69 \mathrm{~s} \mathrm{~m}^{-1}$ is $14.4 \mathrm{~mm} \mathrm{~s}^{-1}$.

The current global $\mathrm{CO}_{2}$ concentration is about $372 \mathrm{ppm}$ and it is projected to reach about 550 ppm by 2050 and more than $700 \mathrm{ppm}$ by 2100 (Prentice et al., 2001). For Scenario $\mathrm{A} 2$, the atmospheric $\mathrm{CO}_{2}$ concentrations simulated by models will range between 730 and 1020 ppm by 2100 (Meehl, 2007). Long et al. (2004) observed decreased stomata conductance by $20 \%$ average for $\mathrm{C} 3$ plants grown in elevated $\mathrm{CO}_{2}$ concentration (about $550 \mathrm{ppm}$ ) in FACE (FreeAir $\mathrm{CO}_{2}$ Enrichment), based on more than 200 independent measurements. This decrease of stomatal conductance was observed for 28 species (Drake et al., 1997). Considering this is true for the stomatal conductance of $0.12 \mathrm{~m}$ tall 
$\mathrm{C}_{3}$ species of grass with a canopy resistance of $69 \mathrm{~s} \mathrm{~m}^{-1}$, the stomatal conductance for $\mathrm{C}_{3}$ grass should decrease from about $14.4 \mathrm{~mm} \mathrm{~s}^{-1}$ to $11.4 \mathrm{~mm} \mathrm{~s}^{-1}$, which corresponds to $r_{\mathrm{s}}=125 \mathrm{~s} \mathrm{~m}^{-1}$. Using the same approach to calculate $r_{\mathrm{c}}$ in the $\mathrm{ET}_{\mathrm{o}}$ equation (Allen et al., 1998), the $r_{\mathrm{c}}$ for $550 \mathrm{ppm}$ is calculated as:

$r_{\mathrm{c}}=\frac{r_{\mathrm{s}}}{0.5 \times \mathrm{LAI}}=\frac{125 \mathrm{~s} \mathrm{~m}^{-1}}{0.5 \times 2.88} \approx 87 \mathrm{~s} \mathrm{~m}^{-1}$

For the reasons stated above, we can assume an increasing $\mathrm{CO}_{2}$ concentration from 372 to $550 \mathrm{ppm}$ should increase stomatal resistance from about $70 \mathrm{~s} \mathrm{~m}^{-1}$ to about $87 \mathrm{~s} \mathrm{~m}^{-1}$.

Dew point temperature $\left(T_{\mathrm{d}}\right)$ in ${ }^{\circ} \mathrm{C}$ is calculated using the expression (5):

$T_{\mathrm{d}}=237.3\left[\frac{\frac{\ln \left(e_{a} / 0.6108\right)}{17.27}}{1-\frac{\ln \left(e_{a} / 0.6108\right)}{17.27}}\right]$

where $e_{\mathrm{a}}$ is actual vapour pressure (kPa).

Four scenarios have been considered for the estimation of $\mathrm{ET}_{\mathrm{o}} 50 \mathrm{yr}$ from now:

- Scenario 1: annual trends of the climatic variables of $T_{\max }, T_{\min }, T_{\mathrm{d}}, R_{\mathrm{n}}$ and $U$ with annual concentrations of $\mathrm{CO}_{2}$ of $372 \mathrm{ppm}$.

- Scenario 2: annual trends of the climatic variables of $T_{\max }, T_{\min }, T_{\mathrm{d}}, R_{\mathrm{n}}$ and $U$ with annual concentrations of $\mathrm{CO}_{2}$ of $550 \mathrm{ppm}$.

- Scenario 3: monthly trends of the climatic variables of $T_{\max }, T_{\min }, T_{\mathrm{d}}, R_{\mathrm{n}}$ and $U$ with annual concentrations of $\mathrm{CO}_{2}$ of $372 \mathrm{ppm}$ and

- Scenario 4: monthly trends of the climatic variables of $T_{\max }, T_{\min }, T_{\mathrm{d}}, R_{\mathrm{n}}$ and $U$ with annual concentrations of $\mathrm{CO}_{2}$ of $550 \mathrm{ppm}$.

The estimation of $\mathrm{ET}_{\mathrm{o}}$ in the Duero River basin under different future situations was carried out with a simple Excel application called EEE (Estimation de la Evapotranspiracion en España). With the daily data of the 38 stations and the expression (1), the $\mathrm{ET}_{\mathrm{o}}$ was estimated for 2007, for different simulations, and was represented as a map with the Surfer ${ }^{\circledR}$ 8 program by means of the Kriging method.

\section{Results and discussion}

\subsection{Variable climate and trends}

In Table 1, we see the description and trends of the climatic variables for the period 1980-2009. The maximum temperature has an average annual value of $17.8 \pm 0.6^{\circ} \mathrm{C}$, reaching the maximum value in the month of July $\left(29.0 \pm 1.32^{\circ} \mathrm{C}\right)$ and the minimum in January $\left(7.8 \pm 1.17^{\circ} \mathrm{C}\right)$. For the minimum temperature we obtained an average annual value of
$5.75 \pm 0.6^{\circ} \mathrm{C}$, showing the maximum value in the month of August $\left(13.0 \pm 1.17^{\circ} \mathrm{C}\right)$ and the minimum in January $\left(-0.5^{\circ} \mathrm{C} \pm 1.17\right)$. The dew point is seen to be similar to the minimum temperature with the same behavior in relation to the months with the maximum and minimum. The wind velocities and the net radiation had annual values of $3.05 \pm 0.35 \mathrm{~m} \mathrm{~s}^{-1}$ and $8.19 \pm 0.17 \mathrm{MJ} \mathrm{m}^{-2} \mathrm{~d}^{-1}$, respectively.

Annually, we observe a positive trend in the variables $T_{\max }, T_{\min }, U$ and $R_{\mathrm{n}}$ although only $T_{\max }, T_{\min }$ and $R_{\mathrm{n}}$ show significant trends at $\geq 95 \%$ level according to the MannKendall test statistics. The dew point shows negative trends although it does not present significant differences at the $\geq 95 \%$ level. The trend of $T_{\max }$ and of $T_{\min }$ is of $0.03^{\circ} \mathrm{C} \mathrm{yr}^{-1}$ for the period 1980-2009. The temperature increase that Spain will suffer in the future will be in the range of $0.3^{\circ} \mathrm{C}$ and $0.7^{\circ} \mathrm{C}$ per decade depending on the area; for the Duero Basin, the increments of $T_{\max }$ are $T_{\min }$ are of $0.52^{\circ} \mathrm{C}$ and 0.48 per decade, respectively, for the period 1973-2002 (Moratiel et al., 2010).

Authors such as Brunet et al. (2007) observed temperature increases around $0.5^{\circ} \mathrm{C}$ per decade for the period 19732005. Studies in different regions of Spain have been done by various authors. Ramos et al. (2008) found trends of $0.5^{\circ} \mathrm{C}$ per decade in the Ebro River and Inner Catalonia basins for the period between 1967-2005. Del Rio et al. (2007) showed lower trends than those of this study for $T_{\max }$ and $T_{\min }$ with values of $0.2{ }^{\circ} \mathrm{C}$ and $0.1^{\circ} \mathrm{C}$ per decade, respectively, for the Duero River Basin during 1961-1997. Nevertheless, when this series is compared with series for more recent periods, this trend increases (Brunet et al., 2007).

In Table 1 , we see that the monthly trends of $T_{\max }$ and $T_{\min }$ are very different, with positive trends observed in all months except September, November, and December, which have negative trends. The months in which the trends of the $T_{\max }$ and $T_{\min }$ presented significant differences at the level $\geq 95 \%$ were May and June. For May we observed trends of $0.115^{\circ} \mathrm{C} \mathrm{yr}^{-1}$ and $0.08^{\circ} \mathrm{C} \mathrm{yr}^{-1}$ for $T_{\max }$ and $T_{\min }$, respectively, while for June it was of $0.13^{\circ} \mathrm{C} \mathrm{yr}^{-1}$ for $T_{\max }$ and $0.094^{\circ} \mathrm{C} \mathrm{yr}^{-1}$ for $T_{\min }$. Christensen et al. (2007) showed higher positive trends in average temperature during the summer months than for the winter months in the south of Europe. According to Kjellstroström et al. (2007), the range of change in daily maximum temperatures for June, July and August (JJA) is between $3{ }^{\circ} \mathrm{C}$ and $9{ }^{\circ} \mathrm{C}$ and between $1{ }^{\circ} \mathrm{C}$ and $5^{\circ} \mathrm{C}$ for daily minimum in the Iberian Peninsula considering ten regional climate model (RMC) with a future scenario period (A2), 2071-2100. These authors observed that the differences between models are larger for the extremes (maximum and minimum) than for mean temperatures. These models behave differently and there is no established way to tell which one represents the most probable version of the future (Déqué et al., 2007). This is the reason why multimodel ensamble analysis at European (Christensen and Chistensen, 2007) and Spanish scale (Ruiz-Ramos and Miguez, 2010) 
Table 1. Descriptive and conditional Mann-Kendall test (MK-test) statistics for variables Maximum Temperature $\left(T_{\max }\right)$, Minimum Temperature $\left(T_{\min }\right)$, Dew Point $\left(T_{\mathrm{d}}\right)$, Wind Speed $(U)$, and Net Radiation $\left(R_{\mathrm{n}}\right)$ in stations in the Duero Basin for the period 1980-2009. The numbers in bold indicate significant trends at $\geq 95 \%$ level.

\begin{tabular}{|c|c|c|c|c|c|c|c|c|c|c|c|c|c|c|}
\hline \multicolumn{2}{|c|}{ Variable } & Annual & Jan & Feb & Mar & Apr & May & Jun & Jul & Aug & Sep & Oct & Nov & Dec \\
\hline \multirow{5}{*}{$T_{\max }\left({ }^{\circ} \mathrm{C}\right)$} & Mean & 17.8 & 7.8 & 10.3 & 14.0 & 15.4 & 19.5 & 25.3 & 29.0 & 28.6 & 24.3 & 17.9 & 11.9 & 9.9 \\
\hline & $\mathrm{SD}$ & 0.60 & 1.17 & 1.85 & 1.88 & 1.97 & 2.28 & 2.29 & 1.32 & 1.43 & 1.95 & 2.03 & 1.61 & 0.95 \\
\hline & Trend $\mathrm{yr}^{-1}$ & 0.030 & 0.014 & 0.048 & 0.043 & 0.070 & 0.115 & 0.130 & 0.023 & 0.018 & -0.040 & 0.014 & -0.025 & -0.029 \\
\hline & MK-test & 2.43 & 0.46 & 0.93 & 1.04 & 1.43 & 2.34 & 2.91 & 0.79 & 0.50 & -0.64 & 0.21 & -0.54 & -1.39 \\
\hline & $p$ & 0.02 & 0.64 & 0.35 & 0.30 & 0.15 & 0.02 & 0.00 & 0.43 & 0.62 & 0.34 & 0.83 & 0.59 & 0.16 \\
\hline \multirow{5}{*}{$T_{\min }\left({ }^{\circ} \mathrm{C}\right)$} & Mean & 5.8 & -0.5 & 0.0 & 2.0 & 3.6 & 7.0 & 10.71 & 12.91 & 13.0 & 10.3 & 6.8 & 2.7 & 0.6 \\
\hline & SD & 0.60 & 1.77 & 1.66 & 1.33 & 1.22 & 1.32 & 1.25 & 1.11 & 1.17 & 1.34 & 1.22 & 1.79 & 2.28 \\
\hline & Trend $\mathrm{yr}^{-1}$ & 0.030 & 0.046 & 0.013 & 0.028 & 0.050 & 0.080 & 0.094 & 0.022 & 0.027 & -0.013 & 0.056 & -0.002 & -0.028 \\
\hline & MK-test & 2.07 & 0.98 & 0.07 & 0.87 & 1.52 & 2.57 & 3.41 & 0.75 & 0.89 & -0.50 & 1.82 & -0.02 & -0.55 \\
\hline & $p$ & 0.04 & 0.33 & 0.94 & 0.38 & 0.13 & 0.01 & 0.00 & 0.45 & 0.37 & 0.62 & 0.07 & 0.99 & 0.58 \\
\hline \multirow{5}{*}{$T_{\mathrm{d}}\left({ }^{\circ} \mathrm{C}\right)$} & Mean & 5.6 & 0.9 & 1.1 & 2.2 & 3.5 & 6.5 & 9.3 & 10.4 & 10.9 & 9.6 & 7.3 & 3.8 & 1.9 \\
\hline & $\mathrm{SD}$ & 0.49 & 1.41 & 1.73 & 1.37 & 1.23 & 1.17 & 0.88 & 1.06 & 1.03 & 1.32 & 1.04 & 1.64 & 1.97 \\
\hline & Trend $\mathrm{yr}^{-1}$ & -0.015 & 0.025 & -0.007 & -0.006 & 0.012 & 0.039 & 0.000 & -0.071 & -0.064 & -0.080 & 0.013 & -0.048 & -0.043 \\
\hline & MK-test & -1.18 & 0.82 & -0.11 & -0.14 & 0.57 & 1.64 & 0.04 & -2.53 & -2.53 & -2.36 & 0.61 & -1.25 & - \\
\hline & $p$ & 0.24 & 0.41 & 0.92 & 0.89 & 0.57 & 0.10 & 0.97 & 0.01 & 0.01 & 0.02 & 0.54 & 0.21 & 0.35 \\
\hline \multirow{5}{*}{$U\left(\mathrm{~m} \mathrm{~s}^{-1}\right)$} & Mean & 3.0 & 2.8 & 2.9 & 3.4 & 3.6 & 3.4 & 3.1 & 3.1 & 2.9 & 2.7 & 2.8 & 2.7 & 3.3 \\
\hline & SD & 0.35 & 0.85 & 0.65 & 0.60 & 0.62 & 0.53 & 0.44 & 0.41 & 0.48 & 0.42 & 0.64 & 0.68 & 0.80 \\
\hline & Trend $\mathrm{yr}^{-1}$ & 0.017 & 0.023 & 0.023 & 0.016 & 0.005 & 0.002 & 0.015 & 0.017 & 0.027 & 0.015 & 0.012 & 0.040 & 0.018 \\
\hline & MK-test & 1.82 & 1.50 & 1.55 & 1.11 & 0.38 & 0.09 & 1.38 & 1.70 & 2.52 & 1.82 & 0.88 & 2.71 & 1.00 \\
\hline & $p$ & 0.07 & 0.13 & 0.12 & 0.27 & 0.71 & 0.93 & 0.17 & 0.09 & 0.01 & 0.07 & 0.38 & 0.01 & 0.32 \\
\hline \multirow{5}{*}{$\begin{array}{l}R_{\mathrm{n}} \\
\left(\mathrm{MJ} \mathrm{m}^{-2} \mathrm{~d}^{-1}\right)\end{array}$} & Mean & 8.2 & 2.2 & 4.2 & 7.4 & 10.5 & 12.8 & 14.9 & 14.9 & 12.6 & 9.1 & 5.3 & 2.6 & 1.7 \\
\hline & SD & 0.17 & 0.09 & 0.20 & 0.50 & 0.58 & 0.82 & 0.82 & 0.60 & 0.70 & 0.30 & 0.28 & 0.11 & 0.15 \\
\hline & Trend $\mathrm{yr}^{-1}$ & 0.009 & 0.000 & 0.007 & 0.005 & 0.018 & 0.012 & 0.017 & 0.033 & 0.028 & 0.007 & 0.002 & 0.001 & -0.003 \\
\hline & MK-test & 2.18 & 0.34 & 1.80 & 0.54 & 1.29 & 0.63 & 1.16 & 2.45 & 3.18 & 0.80 & 0.21 & 0.25 & 0.86 \\
\hline & $p$ & 0.03 & 0.73 & 0.07 & 0.59 & 0.20 & 0.53 & 0.25 & 0.01 & 0.00 & 0.42 & 0.83 & 0.80 & 0.39 \\
\hline
\end{tabular}

are being applied. The analysis of possible regional climate changes over Europe, simulated by 10 regional climate models within PRUDENCE context, has indicated that PROMES (Jacob et al., 2007) is one of the best models adapted to the Iberian Peninsula, showing similar tendencies obtained by this study.

In Spain for the period between 1973 and 2005, the trends of the $T_{\max }$ were significant for spring and summer with values of 0.082 and $0.073{ }^{\circ} \mathrm{C}$ per year, respectively. The $T_{\min }$ behaved in a similar way with trends of $0.066^{\circ} \mathrm{C} \mathrm{yr}^{-1}$ for spring and $0.062^{\circ} \mathrm{C} \mathrm{yr}^{-1}$ for summer (Brunet et al., 2007). At the regional level in the Spanish Northeast, for the period 19752004, Martínez et al. (2010) showed values similar to those obtained in this study, with a higher trend of $T_{\max }$ and $T_{\min }$ for spring and summer $\left(0.8-0.9^{\circ} \mathrm{C} \mathrm{decade}^{-1}\right)$ with respect to the annual $T_{\max }$ and $T_{\min }$ trend $\left(0.5^{\circ} \mathrm{Cdecade}^{-1}\right)$. When we consider other periods of earlier temporal series, these seasonal differences are not detected (Brunet et al., 2007; Del Rio et al., 2007).

There is not much information with relation to trends in relative humidity and dew point temperature $\left(T_{\mathrm{d}}\right)$. In more humid regions $T_{\mathrm{d}}$ is very close to $T_{\min }$. Table 1 shows how $T_{\mathrm{d}}$ are very close to $T_{\min }$. This difference becomes much greater in the summer months when the relative humidities are lower than in other months. These months (July, August, and September) with the maximum difference between $T_{\min }$ and $T_{\mathrm{d}}$ are when the significant negative trends are observed at the $\geq 95 \%$ level with inclines between $-0.06^{\circ} \mathrm{C} \mathrm{yr}^{-1}$ and $-0.08^{\circ} \mathrm{C} \mathrm{yr}^{-1}$. Authors such as Robinson (2000) showed $T_{\mathrm{d}}$ trends of $+0.01{ }^{\circ} \mathrm{C}$ per year for the USA for the period from 1951 to 1990 , although these trends were reduced in the summer. According to Trenberth et al. (2007), the global trends in specific humidity have values of $e 0.06 \mathrm{~g} \mathrm{~kg}^{-1}$ per decade (1976-2004), which assumes a ratio of an increase of $4.3 \%$ per $1{ }^{\circ} \mathrm{C}$, suggesting a modest reduction in relative humidity as temperatures increase, as expected in water-limited regions. Moratiel et al. (2010) showed negative trends of relative humidity for the Duero River Basin with decreases of $0.5 \%$ per decade in maximum relative humidity and of $1.6 \%$ in minimum relative humidity. These declines in the relative humidities will cause decreases in $T_{\mathrm{d}}$.

Table 1 displays trends in relation to the wind velocity variable, with positive trends in all months. Low-level studies show a tendency towards higher wind speed (Carnell et al., 1996). According to Christensen et al. (2007), there will be increases in the southern part of Europe of no more than $5 \%$. The annual wind velocity increase is of $0.017 \mathrm{~m} \mathrm{~s}^{-1}$ per year which shows a trend very similar to that reported by Thomas et al. (2008) with increases of $0.02 \mathrm{~m} \mathrm{~s}^{-1}$ per year. The months that represented significant differences were August and November, also showing greater trends with increases of $0.027 \mathrm{~m} \mathrm{~s}^{-1}$ and $0.040 \mathrm{~m} \mathrm{~s}^{-1}$ per year, respectively. 
Table 1 shows a positive trend of net radiation of $0.009 \mathrm{MJ} \mathrm{m}^{-1}$ day $^{-1}$ with significant differences at the annual level. All months showed positive trends except December. July and August are the months with significant differences in these trends. With relation to the trends of solar radiation, there are studies that report a negative trend ("dimming") with decreases of $7 \mathrm{~W} \mathrm{~m}^{-2}$ per decade for the period 1961-1990 with observation around the world (Liepert, 2002). Negative trends in China were observed by Ren et al. (2005) and in the Mediterranean by Omran (2000). Recent studies show that there is a positive trend for periods after the 80s (Wild et al., 2005) with increments on a global level of $0.16 \mathrm{~W} \mathrm{~m}^{-2}$ (Pinker et al., 2005). Positive trends for years after the 1980s were also detected for Spain (SanchezLorenzo et al., 2009). These same trends were detected in our study in an indirect way through $R_{\mathrm{n}}$ for the period between 1980-2009.

\subsection{Scenarios obtained}

The scenarios given for the estimation of the future situation of the $\mathrm{ET}_{\mathrm{o}} 50 \mathrm{yr}$ from now were done considering those climatic variables (Table 1) that showed significant differences in trends at the $95 \%$ level through the statistical test of the Mann-Kendall equation. These scenarios were done on an annual and monthly basis with different concentrations of $\mathrm{CO}_{2}$ : current $(372 \mathrm{ppm})$ and future $(50 \mathrm{ppm})$. Scenario 1 considers annual trends with current $\mathrm{CO}_{2}$ concentrations; Scenario 2 considers annual trends with future concentrations of $\mathrm{CO}_{2}$; Scenario 3, the monthly trends with current $\mathrm{CO}_{2}$ concentrations; and Scenario 4, the monthly trends with future $\mathrm{CO}_{2}$ concentrations (Table 2).

\subsection{Future evapotranspiration}

Table 3 shows the reference evapotranspiration $\left(\mathrm{ET}_{\mathrm{o}}\right)$ by year, using 2007 as the base year and the increases of the same for the different scenarios. The average annual $\mathrm{ET}_{\mathrm{o}}$ is of $1042 \mathrm{~mm}$, below the annual average of Spain $(1196 \mathrm{~mm})$ for this year (Moratiel et al., 2010). The minimum values of $\mathrm{ET}_{\mathrm{o}}$ are found in December $(18.6 \mathrm{~mm})$ which represents $1.8 \%$ of the annual $\mathrm{ET}_{\mathrm{o}}$, while the maximum values are found in the month of July $(179.1 \mathrm{~mm})$ with $17.2 \%$ of the annual $\mathrm{ET}_{\mathrm{o}}$. Considering the $\mathrm{ET}_{\mathrm{o}}$ of the months of May, June, July, August and September, this makes up $68 \%$ of the annual $\mathrm{ET}_{\mathrm{o}}$; these months also only account for $33 \%$ of the annual precipitation (Ceballos et al., 2004). In the four scenarios given, there is an annual $\mathrm{ET}_{\mathrm{o}}$ increment with percentages from $11 \%$ in Scenario 3 to $5 \%$ in Scenario 2. The trends shown in the $\mathrm{ET}_{\mathrm{o}}$ increases are of 2, 1.1, 2.3 and $1.4 \mathrm{~mm} \mathrm{yr}^{-1}$ for scenarios $1,2,3$ and 4 respectively. Authors such as Donohue et al. (2010) showed decreases in $\mathrm{ET}_{\mathrm{o}}$ for Australia of $0.8 \mathrm{~mm} \cdot \mathrm{yr}^{-1}$, principally due to the negative trends in wind velocity and net radiation. The increase in $\mathrm{ET}_{\mathrm{o}}$ in the scenarios with a greater concentration of $\mathrm{CO}_{2}$

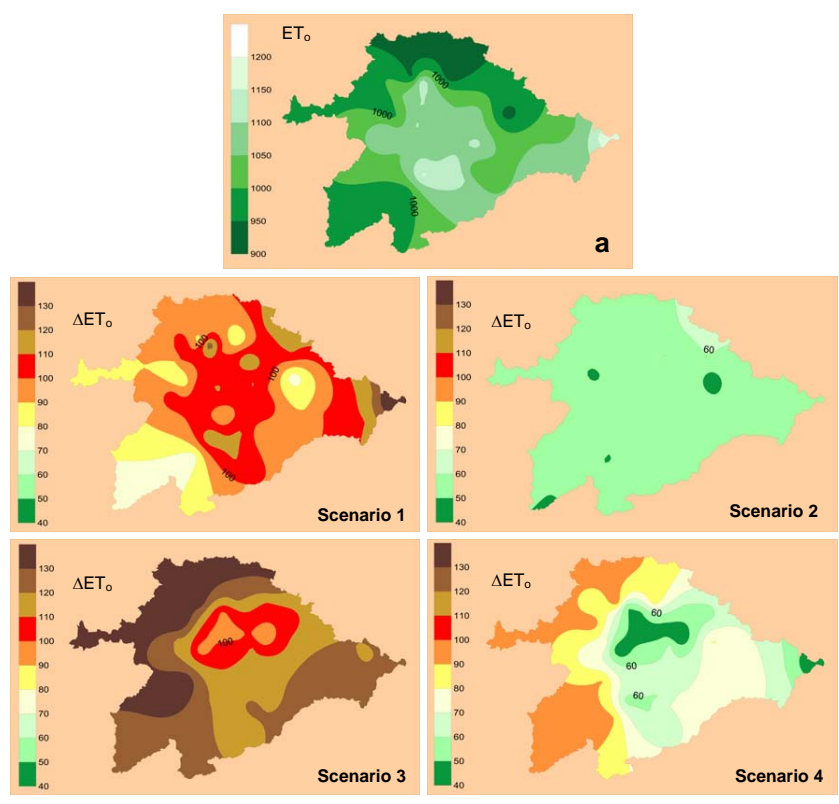

Fig. 2. (a) Annual $\mathrm{ET}_{\mathrm{o}}(\mathrm{mm})$ for reference year 2007 and increases $\left(\Delta \mathrm{ET}_{\mathrm{o}}, \mathrm{mm}\right)$ by $50 \mathrm{yr}$ according to scenarios $1,2,3$ and 4 .

(scenarios 2 and 4) is lower than in the scenarios with a lower concentration of $\mathrm{CO}_{2}$ (scenarios 1 and 3 ). In Table 3 we see how the increase of $\mathrm{CO}_{2}$ from $372 \mathrm{ppm}$ to $550 \mathrm{ppm}$ creates a reduction of the $\mathrm{ET}_{\mathrm{o}}$ increment by half (Scenario 1 versus Scenario 2 and Scenario 3 versus Scenario 4).

Various authors showed that the evapotranspiration trends as a response to climate change would be found within a range of increases between $10 \%$ and $20 \%$. Since the end of the 1980's, Martin et al. (1989) and Rosenberg et al. (1989) reported increases of $17 \%$ with an air temperature increase of $3{ }^{\circ} \mathrm{C}$ based on measurements taken during summer in northeastern Kansas, with temperatures ranging between 24 and $35^{\circ} \mathrm{C}$. In agreement with the studies done in California by Anderson et al. (2008) with an air temperature increase of $3{ }^{\circ} \mathrm{C}$ causing an $\mathrm{ET}_{\mathrm{o}}$ increment of $18.7 \%$, these authors show that if the $\mathrm{CO}_{2}$ concentration increases this percentage diminishes. Goyal (2004) in the region of Rajasthan, India reported that reference evapotranspiration increments of $12.7 \%$ can happen with air temperature increments of $1 \%$. All these authors show that small changes in the climatic variables can have important consequences in arid climates where the scarcity of water is a grave problem.

Moratiel et al. (2010) shows ET $_{\mathrm{o}}$ increments between $7 \%$ and $36 \%$ for Spain at the end of the twenty-first century. These increases are slightly higher to those reported in this study. Moratiel et al. (2010) used 100 instead of $50 \mathrm{yr}$ period. In addition, these authors only considered the variations in air temperature and relative humidity.

$\mathrm{ET}_{\mathrm{o}}$ is used mainly to calculate the irrigation needs of a specific crop $\left(\mathrm{ET}_{\mathrm{c}}\right)$. $\mathrm{ET}_{\mathrm{c}}$ is often estimated by multiplying the reference crop evapotranspiration $\left(\mathrm{ET}_{\mathrm{o}}\right)$ by a crop 
Table 2. Scenarios generated in the Basin according to the trends of the climate variables obtained in Table 1. $r_{\mathrm{c}}$ surface resistance as a consequence of the $\mathrm{CO}_{2}$ increase from $372 \mathrm{ppm}\left(r_{\mathrm{c}}=70\right)$ to $550 \mathrm{ppm}\left(r_{\mathrm{c}}=87\right)$.

\begin{tabular}{|c|c|c|c|c|c|c|c|c|}
\hline Scenarios & Period & & $\begin{array}{l}T_{\max } \\
\left({ }^{\circ} \mathrm{C}\right)\end{array}$ & $\begin{array}{l}T_{\min } \\
\left({ }^{\circ} \mathrm{C}\right)\end{array}$ & $\begin{array}{c}T_{\mathrm{d}} \\
\left({ }^{\circ} \mathrm{C}\right)\end{array}$ & $\begin{array}{c}U \\
\left(\mathrm{~m} \mathrm{~s}^{-1}\right)\end{array}$ & $\begin{array}{c}R_{\mathrm{n}} \\
\left(\mathrm{MJ} \mathrm{m}^{2} \mathrm{~d}^{-1}\right)\end{array}$ & $\begin{array}{c}r_{\mathrm{c}} \\
\left(\mathrm{s} \mathrm{m}^{-1}\right)\end{array}$ \\
\hline 1 & Yearly & & 0.030 & 0.030 & 0 & 0 & 0.009 & 70 \\
\hline 2 & Yearly & & 0.030 & 0.030 & 0 & 0 & 0.009 & 87 \\
\hline \multirow[t]{12}{*}{3} & Monthly & 1 & 0 & 0 & 0 & 0 & 0 & 70 \\
\hline & & 2 & 0 & 0 & 0 & 0 & 0 & 70 \\
\hline & & 3 & 0 & 0 & 0 & 0 & 0 & 70 \\
\hline & & 4 & 0 & 0 & 0 & 0 & 0 & 70 \\
\hline & & 5 & 0.115 & 0.08 & 0 & 0 & 0 & 70 \\
\hline & & 6 & 0.13 & 0.094 & 0 & 0 & 0 & 70 \\
\hline & & 7 & 0 & 0 & -0.071 & 0 & 0.033 & 70 \\
\hline & & 8 & 0 & 0 & -0.064 & 0.027 & 0.028 & 70 \\
\hline & & 9 & 0 & 0 & -0.08 & 0 & 0 & 70 \\
\hline & & 10 & 0 & 0 & 0 & 0 & 0 & 70 \\
\hline & & 11 & 0 & 0 & 0 & 0.04 & 0 & 70 \\
\hline & & 12 & 0 & 0 & 0 & 0 & 0 & 70 \\
\hline \multirow[t]{12}{*}{4} & Monthly & 1 & 0 & 0 & 0 & 0 & 0 & 87 \\
\hline & & 2 & 0 & 0 & 0 & 0 & 0 & 87 \\
\hline & & 3 & 0 & 0 & 0 & 0 & 0 & 87 \\
\hline & & 4 & 0 & 0 & 0 & 0 & 0 & 87 \\
\hline & & 5 & 0.115 & 0.08 & 0 & 0 & 0 & 87 \\
\hline & & 6 & 0.13 & 0.094 & 0 & 0 & 0 & 87 \\
\hline & & 7 & 0 & 0 & -0.071 & 0 & 0.033 & 87 \\
\hline & & 8 & 0 & 0 & -0.064 & 0.027 & 0.028 & 87 \\
\hline & & 9 & 0 & 0 & -0.08 & 0 & 0 & 87 \\
\hline & & 10 & 0 & 0 & 0 & 0 & 0 & 87 \\
\hline & & 11 & 0 & 0 & 0 & 0.04 & 0 & 87 \\
\hline & & 12 & 0 & 0 & 0 & 0 & 0 & 87 \\
\hline
\end{tabular}

Table 3. Mean monthly reference evapotranspiration $\left(\mathrm{ET}_{\mathrm{O}}, \mathrm{mm}\right)$ and increments $\left(\Delta \mathrm{ET}_{\mathrm{O}}\right)$ of the four scenarios according to Table 2. Data are based on 38 stations using the reference year of 2007.

\begin{tabular}{|c|c|c|c|c|c|c|c|c|c|}
\hline \multirow{3}{*}{ Month } & \multirow{3}{*}{$\begin{array}{r}\mathrm{ET}_{\mathrm{o}} \\
(\mathrm{mm})\end{array}$} & \multicolumn{8}{|c|}{$\Delta \mathrm{ET}_{\mathrm{o}}$} \\
\hline & & \multicolumn{2}{|c|}{ Scenario 1} & \multicolumn{2}{|c|}{ Scenario 2} & \multicolumn{2}{|c|}{ Scenario 3} & \multicolumn{2}{|c|}{ Scenario 4} \\
\hline & & $(\mathrm{mm})$ & $(\%)$ & $(\mathrm{mm})$ & $(\%)$ & $(\mathrm{mm})$ & $(\%)$ & $(\mathrm{mm})$ & $(\%)$ \\
\hline Jan & 20.8 & 5.1 & 25 & 3.8 & 18 & 0.0 & 0 & -1.1 & -5 \\
\hline $\mathrm{Feb}$ & 39.0 & 8.3 & 21 & 5.1 & 13 & 0.0 & 0 & -2.6 & -7 \\
\hline Mar & 70.7 & 9.7 & 14 & 4.9 & 7 & 0.0 & 0 & -4.3 & -6 \\
\hline Apr & 92.4 & 9.3 & 10 & 5.0 & 5 & 0.0 & 0 & -4.1 & -4 \\
\hline May & 120.6 & 11.7 & 10 & 5.7 & 5 & 34.9 & 28.9 & 28.4 & 24 \\
\hline Jun & 144.5 & 11.0 & 8 & 5.4 & 4 & 36.0 & 24.9 & 30.1 & 21 \\
\hline Jul & 179.1 & 11.2 & 6 & 4.8 & 3 & 16.9 & 9.5 & 10.0 & 6 \\
\hline Aug & 153.4 & 11.0 & 7 & 4.9 & 3 & 44.5 & 29.0 & 33.2 & 22 \\
\hline Sep & 110.7 & 8.8 & 8 & 4.6 & 4 & -35.4 & -32.0 & -35.5 & -32 \\
\hline Oct & 57.4 & 6.3 & 11 & 4.3 & 8 & 0.0 & 0 & -1.9 & -3 \\
\hline Nov & 34.6 & 5.3 & 15 & 3.5 & 10 & 21.5 & 62.1 & 17.2 & 50 \\
\hline Dec & 18.6 & 4.2 & 23 & 3.1 & 17 & 0.0 & 0.2 & -0.9 & -4.8 \\
\hline Anual & 1042 & 101.9 & 10 & 54.9 & 5 & 118.4 & 11 & 68.5 & 7 \\
\hline
\end{tabular}


coefficient $\left(K_{\mathrm{c}}\right): \mathrm{ET}_{\mathrm{c}}=K_{\mathrm{c}} \times \mathrm{ET}_{\mathrm{o}}$ (Allen et al., 1998). From the cultivation point of view, it is important to consider the possible changes in $\mathrm{ET}_{\mathrm{o}}$ in different months of the year. In Spain the irrigated crops usually develop during the spring and summer months; during these months the maximum crop water needs to coincide with the periods of least rain. In Table 3, scenarios 1 and 2 (annual changes in the variables), scenarios 3 and 4 (monthly changes in the variables) obtain very similar annual values, but the $\mathrm{ET}_{\mathrm{o}}$ distribution changes over the months. Considering the annual variations of the climatic variables, the monthly $\mathrm{ET}_{\mathrm{o}}$ increments during the summer months are of 3-8\%. If we consider the monthly changes in the variables, we obtain increments for the summer months of about $20 \%$. For the month of September there is an $\mathrm{ET}_{\mathrm{O}}$ decrease as a consequence of the reduction in wind velocity (Table 2). Considering the most probable future scenario (Scenario 4), we can see that the needs of the crops during the months of May, June, July and August will be $18 \%$ more (with a $K_{\mathrm{c}}$ equal to one and without surface resistance variations of the crops with the $\mathrm{CO}_{2}$ increase). According to Supit et al. (2010), trends in annual crop (wheat) water use in Europe are decreasing and can be explained by a shorter growing season as a result of the higher temperatures. In a shorter growing season less water is needed. Raddatz (2003) also cited the possibility of pushing forward the wheat sowing dates in Canada due to climate warming. In Spain, Guareña et al. (2001) carried out experiments on winter wheat (Tritucum aestivum L.), winter barley (Hordeum vulgare L.) and Maize (Zea mays L.). They reported that reductions in the air temperature during the winter and early spring accelerate the development of the crops, reducing the length of their growth cycle.

Figure 2 represents the $\mathrm{ET}_{\mathrm{o}}$ increments created in the River Basin according to the different scenarios. For the reference year (2007), the average $\mathrm{ET}_{\mathrm{o}}$ of the basin is $1042 \mathrm{~mm}$ with values around $900 \mathrm{~mm}$ in the northern zone and $1200 \mathrm{~mm}$ in the east and central zone of the basin (Fig. 2a). For Scenario 1, Fig. 2 shows that the greater ET $_{0}$ increments are found in the areas with the highest wind velocities. This effect of the wind on the $\mathrm{ET}_{\mathrm{o}}$ increments in future situations as a consequence of climate change was also detected by Moratiel et al. (2010) and Donohue et al. (2010).

With an increase in $\mathrm{CO}_{2}$ concentration this effect is lessened (Snyder et al., 2010), and the windiest areas cause smaller $\mathrm{ET}_{\mathrm{o}}$ increments compared to the situation without $\mathrm{CO}_{2}$, since increased $\mathrm{CO}_{2}$ increases the factor 0.34 that accompanies wind speed in the denominator of Eq. (1) (Fig. 2). When the simulations are run by month (scenarios 3 and 4) the area with the greatest $\mathrm{ET}_{\mathrm{o}}$ increase is the western zone (Fig. 2). In scenarios 3 and 4 the most affected areas change with respect to the situation in scenarios 1 and 2, which is due to the fact that the months in which there are changes in climate variables for these scenarios (May to August) the western and southern parts of the basin have higher $\mathrm{ET}_{0}$.

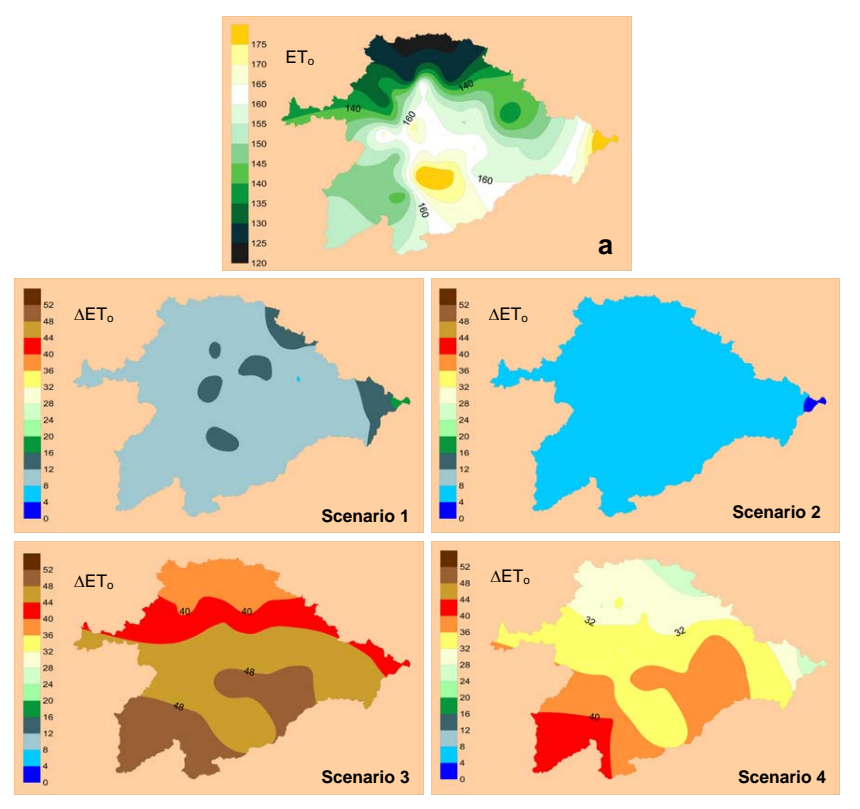

Fig. 3. (a) August $\mathrm{ET}_{\mathrm{o}}(\mathrm{mm})$ for reference year 2007 and increases $\left(\Delta \mathrm{ET}_{\mathrm{o}}, \mathrm{mm}\right)$ by $50 \mathrm{yr}$ according to scenarios $1,2,3$ and 4 .

Keeping in mind that the Duero basin has a dry period of 2 to 5 months (Ceballos et al., 2004) and that the driest months are those which coincide with the maximum $\mathrm{ET}_{\mathrm{o}}$ needs of the crops (July and August), these months present the highest water deficit in the river basin, with the lowest rainfall and highest temperatures. Therefore, the crops' water need is supplied by irrigation. Maize, alfalfa and sugar beet are the most demanding crops during these months. The estimation of the future $\mathrm{ET}_{\mathrm{o}}$ for these months is very important for the management of the basin's water. Figure 3 shows the difference in evapotranspiration for August that exists between between the different scenarios. If we only consider annual increases (scenarios 1 and 2), we observed like the $\mathrm{ET}_{\mathrm{o}}$ increments in the basin values of $10 \mathrm{~mm}$ and $6 \mathrm{~mm}$ respectively. The monthly trends are found to be around 46 and $36 \mathrm{~mm}$ for scenarios 3 and 4 , respectively. This shows that in the months of maximum crop water needs, the $\mathrm{ET}_{\mathrm{o}}$ is 5-6 times greater if monthly variations, as opposed to annual variations, are considered. As in Fig. 2 the situation with increased $\mathrm{CO}_{2}$ diminishes the $\mathrm{ET}_{\mathrm{O}}$ increment.

\section{Conclusions}

The expected climate changes according to the applied scenarios in the Duero Basin will cause an increase in $\mathrm{ET}_{\mathrm{o}}$ between $11 \%(118 \mathrm{~mm})$ and $5 \%(55 \mathrm{~mm})$ in the next $50 \mathrm{yr}$ as compared the to current situation. This annual $\mathrm{ET}_{\mathrm{o}}$ increase does not vary much, taking into account the annual or monthly trends, although the distribution during the months of these increments are totally different. The 
trends of the climatic variables that intervene in evapotranspiration have only been significant for $T_{\max }$ and $T_{\min }$, both with increases of $0.3^{\circ} \mathrm{C}$ per decade, and net radiation with an increase of $0.09 \mathrm{MJ} \mathrm{m}^{-2} \mathrm{~d}^{-1}$ per decade for the period 1980-2009. The months most affected by climate change regarding $\mathrm{ET}_{\mathrm{o}}$ are May, June, July, August and September, months which coincide with the greatest demand for water for crop irrigation in the basin. During May and June, there are significant increments $T_{\max }$ increments of $+0.115^{\circ} \mathrm{C} \mathrm{yr}^{-1}$ and $0.13^{\circ} \mathrm{C} \mathrm{yr}^{-1}$, respectively. $T_{\min }$ showed a positive trend of $0.08^{\circ} \mathrm{C} \mathrm{yr}^{-1}$ and $0.094^{\circ} \mathrm{C} \mathrm{yr}^{-1}$ for May and June, respectively. $T_{\mathrm{d}}$ only changed during the months of July, August and September with trends of $-0.71^{\circ} \mathrm{C} \mathrm{yr}^{-1},-0.064^{\circ} \mathrm{C} \mathrm{yr}^{-1}$ and $-0.08^{\circ} \mathrm{C} \mathrm{yr}^{-1} \mathrm{re}-$ spectively. The wind velocity varied significantly in the months of August and November with values of 0.027 and $0.04 \mathrm{~m} \mathrm{~s}^{-1} \mathrm{yr}^{-1}$, respectively, and net radiation showed significant trends for the months of July and August of 0.033 and $0.028 \mathrm{MJ} \mathrm{m}^{-2} \mathrm{~d}^{-1}$ per $\mathrm{yr}^{-1}$, respectively. The months of May, June, and August showed monthly $\mathrm{ET}_{0}$ increments around $25 \%$, while September showed decrements around $32 \%$. The $\mathrm{CO}_{2}$ increase from $372 \mathrm{ppm}$ to $550 \mathrm{ppm}$ would cause a maximum drop of about $50 \%$ of the $\mathrm{ET}_{\mathrm{o}}$ increment with respect to the same future situation. The part of the basin most affected by these increases will be the western area. It is necessary to know how the crops will behave under these new circumstances, as, although the $\mathrm{ET}_{\mathrm{o}}$, will increase, it is possible that the crop cycles will shorten, which would reduce water comsumption.. The effect potential of adaptations such as cultivar change or shift of $\mathrm{C} 3$ to more $\mathrm{C} 4$ crops, change of planting dates, altered water conservation practices, change to drought-tolerant crop varieties among other possibilities is necessary to consider, too.

Acknowledgements. Thanks are due to the Agencia Estatal de Meteorología (AEMET) for facilitating data collection and especially to José Vicente Moreno for his assistance with the elaboration and manipulation of the map of Spain in Surfer ${ }^{\circledR}$. We thank Ms. Ruiz-Ramos for her useful comments regarding the Regional Climate Models RMCs and the reviewers whose comments greatly improved this paper. The funding provided by the Spanish Ministerio de Ciencia e Innovación (MICINN) through project no. AGL2010-21501/AGR is greatly appreciated.

Edited by: A. Gobin

Reviewed by: G. Rossi and another anonymous referee

\section{References}

AEMET: Agencia estatal de Meteorología, available at: http:// www.aemet.es, 2010.

Allen, R. G., Pereira, L. S., Raes, D., and Smith, M.: Crops evapotranspiration, Guidelines for computing crop requirements, Irrigations and Drainage Paper 56, FAO, Rome, 300 pp., 1998.

Allen, R. G., Pruitt, W. O., Wright, J. L., Howell, T. A., Ventura, F., Snyder, R., Itenfisu, D., Steduto, P., Berengena, J., Baselga, J.,
Smith, M., Pereira, L. S., Raes, D., Perrier, A., Alves, I., Walter, I., and Elliott, R.: A recommendation on standardized surface resistance for hourly calculation of reference ETo by the FAO-56 Penman-Monteith method, Agr. Water Manage., 81, 1-22, 2006.

Alpert, P., Kishcha, P., Kaufman, Y. J., and Schwarzbard, R.: Global dimming or local dimming?, Effect of urbanization on sunlight availability, Geophys. Res. Lett., 32, L17802, doi:10.1029/2005GL023320, 2005.

Anderson, J., Chung, F., Anderson, M., Brekke, L., Easton, D., Ejeta, M., Peterson, R., and Snyder, R.: Progress on incorporating climate change into management of California's water resources, Climate Change, 87, S91-S108, doi:10.1007/s10584007-9353-1, 2008.

Brohan, P., Kennedy, J. J., Harris, I., Tett, S. F. B., and Jones, P. D.: Uncertainty estimates in regional and global observed temperature changes: a new dataset from 1850, J. Geophys.Res., 111, D12106, doi:10.1029/2005JD006548, 2006.

Brunet, M., Jones, P. D., Sigró, J., Saladié, O., Aguilar, E., Moberg, A., Della-Marta, P. M., Lister, D., Walther, A., and López, D.: Temporal and spatial temperature variability and change over Spain during 1850-2005, J. Geophys Res., 112, D12117, doi:10.1029/2006JD008249, 2007.

Carnell, R. E., Senoir, C. A., and Mitchell, J. F. B.: An assessment of measures of storminess: simulated changes in the northern hemisphere winter due to increasing $\mathrm{CO}_{2}$, Clim. Dynam., 12, 467-476, 1996.

Ceballos, A., Martínez-Fernández, J., and Luengo-Ugidos, M. A.: Analaysis of rainfall trend and dry periods on a pluviometric gradient representative of Mediterranean climate in Duero Basin, Spain, J. Arid. Environ., 58, 215-233, 2004.

Ceballos-Barbancho, A., Morán-Tejeda, E., Luengo-Ugidos, M. A., and Lorente-Pinto, J. M.: Water resources and enviromental changes a Mediterranean enviroment: The Routh-west sector of the Duero river basin (Spain), J. Hydrol., 351, 126-138, 2008.

Christensen, J. H. and Christensen, O. B.: A summary of the PRUDENCE model prejections af changes in European climate by the end of this century, Climate Change, 81, 7-30, 2007.

Christensen, J. H., Hewitson, B., Busuioc, A., Chen, A., Gao, X., Held, I., Jones, R., Kolli, R. K., Kwon, W. T., Laprise, R., Magaña Rueda, V., Mearns, L., Menéndez, C. G., Räisänen, J., Rinke, A., Sarr, A., and Whetton, P.: Regional Climate Projections, in: Climate Change 2007, The Physical Science Basis, Contribution of Working Group I to the Fourth Assessment Report of the Intergovernmental Panel on Climate Change, edited by: Solomon, S., Qin, D., Manning, M., Chen, Z., Marquis, M., Averyt, K. B., Tignor, M. and Miller, H. L., Cambridge University Press, Cambridge, United Kingdom and New York, NY, USA, 2007.

Confederación Hidrográfica del Duero: Memoria 2008, available at: http://www.chduero.es/Inicio/Publicaciones/tabid/159/ Default.aspx (last access: 10 December 2010), 205 pp., 2008 (in Spanish).

Déqué, M., Rowell, D.P., Lüthi, D., Giorgi, F., Christensen, J. H., Rockel, B., Jacob, D., Kejellström, E., de Castro, M., and van den Hurk, B.: An intercomparasion of regional climate simulations for Europe: assessing uncertainties in model projections, Climate Change, 81, 53-70, 2007.

Del Rio, S., Fraile, R., Herrero, L., and Penas, A.: Analysis of recent trends in mean maximum and minimum temperatures in a 
region of the NW of Spain (Castilla y León), Theor. Appl. Climatol., 90, 1-12, 2007.

Donohue, R. J., McVicar, T. R., and Roderick, M. L.: Assessing the ability of potential evaporation formulations to capture the dynamics in evaporative demand within a changing climate, J. Hydrol., 386, 186-197, 2010.

Drake, B. G., González-Meler, M. A., and Long, S. P.: More efficient plants: A consequence of rising atmospheric $\mathrm{CO} 2$ ?, Ann. Rev. Plant. Physiol. Plant Mol. Biol., 48, 609-639, 1997.

Fink, A. H., Brücher, T., Krüger, A., Leckebusch, G. C., Pinto, J. G., and Ulbrich, U.: The 2003 European summer heatwaves and drought-synoptic diagnosis and impacts, Weather, 59, 209-216, 2004

Giorgi, F., Hewitson, B., Christensen, J., Fu, C., Jones, R., Hulme, M., Mearns, L. V., Storch, H., and Whetton, P.: Regional climate information-evaluation and projections, in: Climate change 2001: the scientific basis, edited by: Houghton, J. T., Ding, Y., Griggs, D. J., Noguer, M., van der Linden, P., Dai, X., Maskell, K., and Johnson, C. I., Contribution of working group I to the third assessment report of the intergovernmental panel on climate change, Cambridge University Press, 583-638, 2001.

Goyal, R. K.: Sensivity of evapotranspiration to global warming: a case study of arid zone of Rajasthan (India), Agric. Water. Manage., 69, 1-11, 2004.

Guareña, A., Ruiz-Ramos, M., Diaz-Ambrona, C. H., Conde, J. R., and Minguéz, I.: Assessment of climate and agriculture in Spain using climate models, Agron. J., 93, 237-249, 2001.

Hansen, J. E., Ruedy, R., Sato, M., Imhoff, M., Lawrence, W., Easterling, D., Peterson, T., and Karl, T.: A closer look at United States and global surface temperature change, J. Geophys. Res., 106, 23947-23963, doi:10.1029/2001JD000354, 2001.

IPCC: Summary for Policymakers, in: Climate Change 2007: The Physical Science Basis, Contribution of Working Group I to the Fourth Assessment Report of the Intergovernmental Panel on Climate Change, edited by: Solomon, S., Qin, D., Manning, M., Chen, Z., Marquis, M., Averyt, K. B., Tignor, M. and Miller, H. L., Cambridge University Press, Cambridge, United Kingdom and New York, NY, USA, 2007.

Jacob, D., Bärring, L., Christensen, O. B., Christensen, J. H., de Castro, M., Déqué, M., Giorgi, F., Hagemann, S., Hirschi, M., Jones, M., Kellström, E., Lenderink, G., Rockel, B., Sánchez, E., Schär, C., Seneviratne, S. I., Somot, S., van Ulden, A., and van den Hurk, B.: An inter-comparison of regional climate models for Europe: model performance in present-day climate, Climate Change, 81, 31-52, 2007.

Kjellström, E., Bärring, L., Jacob, D., Jones, R., Lenderink, G., and Schär, C.: Modelling daily temperature extremes: recent climate and future changes over Europe, Climate Change, 81, 249-265, 2007.

Lautensach, H.: Geografía de España y Portugal, Vicens Vivens, Barcelona, 814 pp., 1967 (in Spanish).

Liepert, B. G.: Observed reductions of surface solar radiation at sites in the United States and worldwide from 1961 to 1990, Geophys. Res. Lett., 29, 1421, doi:10.1029/2002GL014910, 2002.

Long, S. P., Ainsworth, E. A., Rogers, A., and Ort, D. R.: Rising atmospheric Carbon Dioxide: Plants FACE the future, Annu. Rev. Plant. Biol., 55, 591-628, 2004.

Lugina, K. M., Groisman, Vinnikov, K. Y., Koknaeva, V. V., and Speranskaya, N. A.: Monthly surface air temperature time se- ries area-averaged over the 30-degree latitudinal belts of the globe, 1881-2006, in: Trends: A Compendium of Data on Global Change. Carbon Dioxide Information Analysis Center, Oak Ridge National Laboratory, US Department of Energy, Oak Ridge, TN, USA, available at: http://cdiac.esd.ornl.gov/trends/ temp/lugina/lugina.html (last access: 16 October 2010), 2007.

MARM: Ministerio de Medio Ambiente Medio Rural y Marino. Sistema de Información Climática para el Regadío, available at: http://www.marm.es (last access: 25 April 2011), 2010.

Martin, P., Rosenberg, N. J., and McKenney, M. S.: Sensitivity of evapotranspiration in a wheat field, a forest, and a grassland to changes in climate and direct effects of carbon dioxide, Climate Change, 14, 117-151, 1989.

Martínez, M. D., Serra, C., Burgueño, A., and Lana, X.: Time trends of daily maximum and minimum temperatures in Catalonia (NE Spain) for the period 1975-2004, Int. J. Climatol., 30, 267-290, 2010.

Meehl, G. A., Stocker, T. F., Collins, W. D., Friedlingstein, P., Gaye, A. T., Gregory, J. M., Kitoh, A., Knutti, R., Murphy, J. M., Noda, A., Raper, S. C. B., Watterson, I. G., Weaver, A. G., and Zhao, Z. C.: Global Climate Projections, in: Climate Change 2007: The Physical Science Basis, Contribution of Working Group I to the Fourth Assessment Report of the Intergovernmental Panel on Climate Change, edited by: Solomon, S., Qin, D., Manning, M., Chen, Z., Marquis, M., Averyt, K. B., Tignor, M., and Miller, H. L., Cambridge University Press, Cambridge, United Kingdom and New York, NY, USA, 2007.

Moratiel, R., Duran, J. M., and Snyder, R.: Responses of reference evapotranspiration to changes in atmospheric humidity and air temperature in Spain, Clim. Res., 44, 27-40, 2010.

Omran, M. A.: Analysis of solar radiation over Egypt, Theor. Appl. Climatol., 67, 225-240, 2000.

Pinker, R. T., Zhang, B., and Dutton, E. G.: Do Satellites Detect Trends in Surface Solar Radiation?, Science, 308, 850-854, 2005.

Prentice, I., Farquhar, G., Fasham, M., Goulden, M., Heinmann, M., Jaramillo, V. J., Kheshgi, H. S., Le Quéré, C., Scholes, R. J., and Wallace, D. W. R.: The carbon cycle and atmospheric carbon dioxide. In Climate Change 2001: The Scientific Basis, Contributions of Working Group I to the Third Assessment Report of the Intergovernmental Panel on Climate Change, edited by: Houghton, J. T., Ding, Y., Griggs, D. J., Noguer, M., van der Linden, P. J., Dai, X., Maskell, K., and Jonhson, C. A., Cambridge, UK, Cambridge Univ. Press, 183-238, 2001.

Raddatz, R. L.: Agriculture and Tornadoes on the Canadian Prairies: potential impact of increasing atmospheric $\mathrm{CO}_{2}$ on Summer Severe Weather, Nat. Hazards, 290, 113-122, 2003.

Räisänen, J., Hansson, U., Ullerstig, A., Doscher, R., Graham, L. P., Jones, C., Meier, H. E. M., Samuelsson, P., and Willen, U.: European climate in the late twenty-first century: regional simulations with two driving global models and two forcing scenarios, Clim. Dynam., 22, 13-31, 2004.

Ramos, M. C., Jones, G. V., and Martínez-Casasnovas, J. A.: Structure and trenes in climate parameters affecting winegrape production in northeast Spain, Clim. Res., 38, 1-15, 2008.

Ren, G., Guo, J., Xu, M., Chu Ziying, Z. L., and Li, Q.: Climate change of mainland China over past half century, Acta. Meteorol. Sin. 63, 942-955, 2005 (in Chinese).

Robinson, P. J.: Temporal trends in United States dew point tem- 
peratures, Int. J. Climatol., 20, 985-1002, 2000.

Rosenberg, N. J., McKenney, M. S., and Martin, P.: Evapotranspiration in a greenhouse-warmed world:a rewiew and a simulation, Agr. Forest Meteorol., 47, 303-320, 1989.

Rowell, D. P. and Jones, R. G.: Causes and uncertainty of future summer drying over Europe, Clim. Dynam., 27, 281-299, 2006.

Ruis-Ramos, M. and Mínguez, M.I.: Evaluating uncertainty in climate change impacts on crop productivity in the Iberian Peninsula, Clim. Res., 44, 69-82, 2010.

Smith, T. M. and Reynolds, R. W.: A global mergedland and seasurface temperature reconstruction based on historical observations (1880-1997), J. Climate, 18, 2021-2036, 2005.

Snyder, R. L., Moratiel, R., Song, Z., Swelam, A., Jomaa, I., and Shapland, T.: Evapotranspiration response to Climate, 28th International Horticultural Congress, Lisboa, 22-27 August, 2010.

Supit, I., van Diepen, C. A., Boogaard, H. L., Ludwig, F., and Baruth, B.: Trend analysis of water requeriments, consumption and deficit of field crops in Europe, Agr. Forest Meteorol., 150, 77-88, 2010.

Sanchez-Lorenzo, A., Calbó, J., Brunetti, M., and Deser, C.: Dimming/brightening over the Iberian Peninsula: trend in sunshine duration and cloud cover and their relations with atmospheric circulation, J. Geophys. Res., 114, doi:10.1029/2008JD011394, 2009.
Thomas, B. R., Kent, E. C, Swail, V. R., and Berry, D. I.: Trends in ship wind speeds adjusted for observation method and height, Int. J. Climatol., 28, 747-763, 2008.

Trenberth, K. E., Jones, P. D., Ambenje, P., Bojariu, R., Easterling, D., Klein Tank, A., Parker, D., Rahimzadeh, F., Renwick, J. A., Rusticucci, M., Soden, B., and Zhai, P.: Observations: Surface and Atmospheric Climate Change, in: Climate Change 2007: The Physical Science Basis, Contribution of Working Group I to the Fourth Assessment Report of the Intergovernmental Panel on Climate Change, edited by: Solomon, S., Qin, D., Manning, M., Chen, Z., Marquis, M., Averyt, K. B., Tignor, M. and Miller, H. L., Cambridge University Press, Cambridge, United Kingdom and New York, NY, USA, 2007.

Wild, M., Gilgen, H., Roesch, A., Ohmura, A., Long, C. N., Dutton, E. G., Forgan, B., Kallis, A., Russak, V., and Tsvetkov, A.: From Dimming to Brightening: Decadal Changes in Solar Radiation at Earth's Surface, Science, 308, 847-850, 2005. 